Article

\title{
Nanoparticle Enhanced Antibody and DNA Biosensors for Sensitive Detection of Salmonella
}

\author{
Sumeyra Savas ${ }^{1}$, Aylin Ersoy ${ }^{1}$, Yakup Gulmez ${ }^{1}$, Selcuk Kilic ${ }^{2}$, Belkis Levent ${ }^{2}$ and \\ Zeynep Altintas ${ }^{3, *}$ \\ 1 National Research Institute of Electronics and Cryptology, The Scientific and Technological Research Council \\ of Turkey (TUBITAK), Kocaeli 41470, Turkey; sumeyra.savas@tubitak.gov.tr (S.S.); \\ aylin.ersoy@tubitak.gov.tr (A.E.); yakup.gulmez@tubitak.gov.tr (Y.G.) \\ 2 Turkey Public Health General Headquarter, Ankara 06100, Turkey; selcuk.kilic@sbu.edu.tr (S.K.); \\ belkislevent@hotmail.com (B.L.) \\ 3 Institute of Chemistry, Technical University of Berlin, Straße des 17. Juni 124, Berlin 10623, Germany \\ * Correspondence: zeynep.altintas@tu-berlin.de; Tel.: +49-30-314-23727
}

Received: 12 August 2018; Accepted: 22 August 2018; Published: 27 August 2018

\begin{abstract}
Bacteria-related pathogenic diseases are one of the major health problems throughout the world. Salmonella is a genus of rod-shaped Gram-negative enterobacteria of which more than 2600 serotypes have been identified. Infection with Salmonella can cause salmonellosis, a serious bacterial toxi-infection syndrome associated with gastroenteritis, and paralyphoid and typhoid fevers. Its rapid and sensitive detection is a key to the prevention of problems related to health. This paper describes the development of antibody and DNA sensors for Salmonella detection using a microfluidic-based electrochemical system. Commercial Salmonella typhimurium and Salmonella typhimurium from human stool samples were investigated using standard and nanomaterial-amplified antibody sensors. S. typhimurium could be detected down to $1 \mathrm{cfu} \mathrm{mL}^{-1}$. The specificity of immunoassay was tested by studying with non-specific bacteria including E. coli and S. aureus that revealed only $2.01 \%$ and $2.66 \%$ binding when compared to the target bacterium. On the other hand, the quantification of Salmonella DNA was investigated in a concentration range of 0.002-200 $\mu \mathrm{M}$ using the developed DNA biosensor that demonstrated very high specificity and sensitivity with a detection limit of $0.94 \mathrm{nM}$. Our custom-designed microfluidic sensor offers rapid, highly sensitive, and specific diagnostic assay approaches for pathogen detection.
\end{abstract}

Keywords: Salmonella spp.; pathogen detection; antibody biosensor; DNA biosensor; microfluidicbased electrochemical sensor; nanoparticle enhanced bio-detection; infectious diseases

\section{Introduction}

Foodborne diseases lead to diverse health problems worldwide [1,2]. The World Health Organization reported that Salmonella typhimurium and Salmonella enteritidis are the most common causes of foodborne illnesses all over the world. According to the reports of the European Food Safety Authority, human salmonellosis has resulted in three billion euros loss per year [3]. In some regions, more than $90 \%$ of Salmonella strains isolated from humans until 1970 was S. typhimurium, but now incidence of $S$. enteritidis is also gradually increasing, which has been the most frequently isolated serotype in the last 10 years [4]. The symptoms of Salmonella infection include abdominal pain, fever, nausea, vomiting, diarrhea, dehydration, weakness, and loss of appetite, and the symptoms normally appear 12-72 $\mathrm{h}$ after ingestion of contaminated foods or beverages [5].

There are several methods used for the detection of Salmonella serotypes, such as cultivation techniques [6], enzyme-linked immunosorbent assays (ELISAs) [7], polymerase chain reaction (PCR) 
methods [8-10], and biosensors [11]. The gold standard for detection of Salmonella serotypes are still conventional methods that are sensitive and inexpensive. However, these techniques require more than five days to obtain a result and often lack in providing good specificity and sensitivity. Additionally, the cultivation techniques are generally time consuming and the limit of detection for the analysis is insufficient. The use of biosensor technology is a strong alternative to the other techniques by offering highly sensitive, rapid, and easy-to-use bio-detection principles [12]. Today, biosensors are widely used for pathogen detection and are able to measure bacteria down to $1 \mathrm{cfu} \mathrm{mL}^{-1}$. This is particularly due to the significant impact of nanomaterials on the advancement of biosensors and biosensing principles [13-15]. Furthermore, microbial biosensors often require sample volumes in the microliter range and very short analysis time.

Various transducer systems based on surface plasmon resonance (SPR) [16], quartz crystal microbalance (QCM) [17], and electrochemical sensing strategies [18] have been successfully employed for bacteria detection. Offering very high sensitivity and good detection capacity electrochemical sensors are among the widely used systems for Salmonella quantification $[14,19,20]$. Zhu et al. developed a multichannel electrochemical immunosensor for Salmonella detection by combining the rolling circle amplification with DNA-gold nanoparticles (AuNPs) probe [20]. Afonso et al. reported a disposable immunosensor for electrochemical detection of Salmonella enterica subsp. Enterica serovar Typhimurium LT2 using gold nanoparticles and magneto-immunoassay [14]. Sensitive amperometric detection of Salmonella was also reported [21-24]. Even though great progress has been demonstrated in the Salmonella detection, employing only one antibody in the biosensor design often results in insufficient sensitivity, when the sensor could hardly discriminate between two LPS samples from two different Gram-negative bacteria [25].

To overcome the selectivity problem, herein, we report antibody- and DNA-based biosensors for Salmonella detection using a fully-automated custom-designed microfluidic sensing device (MiSens) [18] that is composed of an electromechanical unit controlling the assay protocol via its integrated software (MiCont ${ }^{\mathrm{TM}}$ ). Normal and gold-nanoparticle amplified sandwich assays were developed and used for the detection of commercial Salmonella samples and real samples from human stool. DNA biosensor was developed by capturing the surface DNA probe on the neutravidin (NA) immobilized sensor surface and then measuring the target Salmonella DNA based on the hybridization reaction that occurs between the target DNA and the surface probe. As the measurement system relies on the enzymatic reaction between horseradish peroxidase (HRP) and $3,3^{\prime}, 5,5^{\prime}$-tetramethylbenzidine (TMB), the detector antibody and the DNA detection probe were both labeled with HRP. We have demonstrated that the developed antibody and DNA biosensors are capable of measuring trace amounts of Salmonella and Salmonella DNA, respectively.

\section{Materials and Methods}

\subsection{Materials and Reagents}

A monoclonal anti-Salmonella antibody was bought from BIO-RAD (Puchheim, Germany). Peroxidase-labeled goat anti-Salmonella secondary antibody (BacTrace ${ }^{\circledR}$ Anti-Salmonella CSA-1 Antibody) and Salmonella typhimurium were purchased from SeraCare Life Sciences (Gaithersburg, MD, USA). Staphylococcus aureus and E. coli from human stool samples were obtained from the Public Health Agency (Ankara, Turkey) for cross-reactivity studies. 11-Mercaptoundecanoic acid (MUDA), phosphate-buffered saline tablets (PBS, $0.01 \mathrm{M}$ phosphate buffer, $0.0027 \mathrm{M}$ potassium chloride and $0.137 \mathrm{M}$ sodium chloride, $\mathrm{pH}$ 7.4), N-hydroxysuccinimide (NHS), analytical grade ethanol, horseradish peroxidase (HRP), ethanolamine, and 3,3',5,5'-tetramethylbenzidine (TMB) ready to use reagent with $\mathrm{H}_{2} \mathrm{O}_{2}$, were purchased from Sigma Aldrich (Poole, UK). The gold nanoparticles in $15 \mathrm{~nm}$ (for DNA assays) and $40 \mathrm{~nm}$ (for antibody assays) sizes were purchased from BBI International (Cardiff, UK). Ultrapure water ( $\left.18 \mathrm{M} \Omega \mathrm{cm}^{-1}\right)$ produced by a Milli-Q water system was used for analyses (Millipore Corp., Tokyo, Japan). 1-Ethyl-3-(3-dimethylaminopropyl)-carbodiimide (EDC) and biotin were purchased 
from Thermo Fisher Scientific (Loughborough, UK). The oligonucleotide sequences (target sequence: 5'-ACCGACGGCGAGACCGACTTT-3'; surface probe: Biotin-5'-CTCACCAGGAGATTACAACATGG; detection probe: Biotin-3'-AGTGGCTAAAAGTCGGTCTC; control surface probe: Biotin-5'CAATATTTGGCGTGAATGGGTCGGAAAACA) for DNA sensor development were obtained from Sentromer DNA Technologies LLC (Istanbul, Turkey).

\subsection{Isolation of Salmonella Typhimurium from Human Stool Samples}

Human stool sample was inoculated onto Salmonella-Shigella and xylose lysine deoxycholate agar mediums, and incubated at $37{ }^{\circ} \mathrm{C}$ overnight. Bacterial culture was identified by using standard biochemical tests (the use of glucose, citrate, and indole by bacteria, the production of gas and $\mathrm{H}_{2} \mathrm{~S}$ upon lactose fermentation of bacteria, the determination of the mobility and the ability to split urea). The cultured colonies used glucose, citrate and indole confirmed the presence of Salmonella bacteria. The isolate was serogrouped and serotyped using polyvalent and monovalent Salmonella antisera (Statens Serum Institut, Copenhagen, Denmark) according to the Kauffmann-White scheme [26]. The colonies that produced $\mathrm{H}_{2} \mathrm{~S}$ were considered as a pure colony based on their morphology. After the confirmation and serotyping, the strain was immediately frozen in tryptic soy broth with $16 \%$ glycerol at $-80{ }^{\circ} \mathrm{C}$.

\subsection{Fully-Automated Microfluidic-Based Electrochemical Sensor with a New Chip Design}

A custom-designed fully-automated electrochemical sensor was used in this study to develop antibody- and DNA-based biosensors for Salmonella detection. The sensor fabrication and its developmental stages were fully described in our earlier studies $[18,27,28]$. Meanwhile, we have realized several drawbacks dealing with device's electronics and mechanics. One of the main problems was electromagnetic noise in the signal. In order to decrease the noise level, two modifications were employed: (1) Increasing of the distance between the microfluidic pumps and the potentiometer. The microfluidic pump spread unwanted magnetic pulses by the pulse width modulation (PWM) mechanism; (2) Applying a coaxial cable structure instead of unscreened cable structure between the biosensor and potentiostat circuit. Herein, we designed and integrated a new chip (Figure 1) to improve the efficiency of the biosensing device and the reproducibility of the assays. The electrodes were designed on the glass slide $(10 \times 20 \mathrm{~mm})$ using a fine metal mask, which was made of a laser-cut patterned stainless steel. Au was deposited on the wafer by means of an electron beam evaporator (Ebeam system Nanovak NVEB-600, Nanovak, Ankara, Turkey). Prior to the application of $\mathrm{Au}(200 \mathrm{~nm})$, a $40 \mathrm{~nm}$ Ti layer was applied on to the wafer as an intermediary adhesive layer to enhance the adhesion between the glass slide and the Au. Each array contains eight working electrodes with a shared Au counter and quasi-reference electrodes. The experiments were carried out using the MiCont ${ }^{\mathrm{TM}}$ software (TUBITAK-BILLGEM, Kocaeli, Turkey) running on a wireless PC. The assay protocols were generated, saved, and used when required.

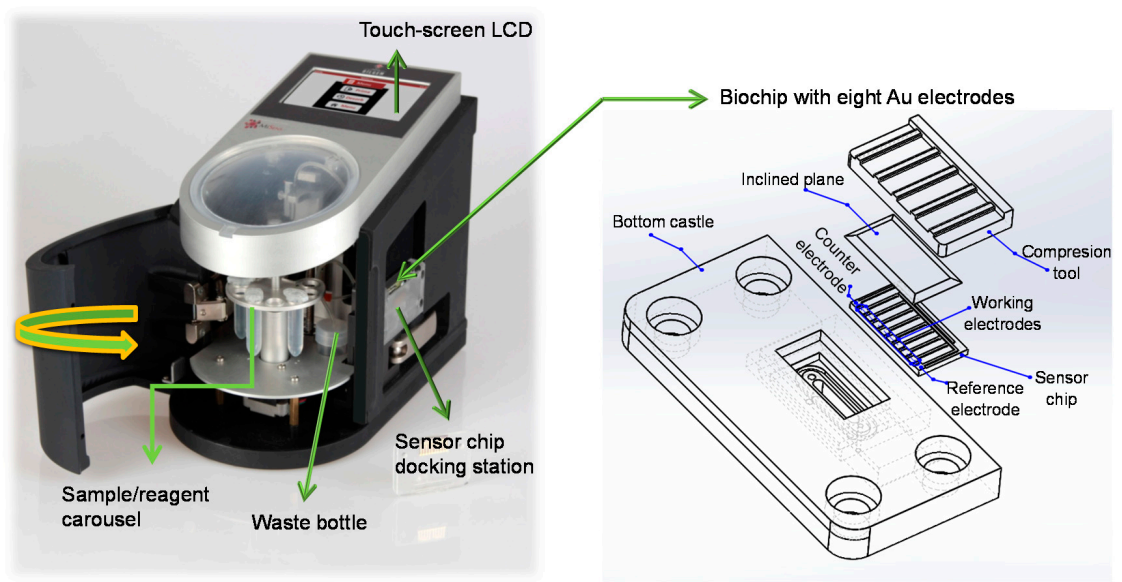

Figure 1. Illustration of MiSens electrochemical sensor and its new chip design. 


\subsection{Sensor Chip Cleaning and SAM Deposition}

Prior to forming a self-assembled monolayer (SAM) on the sensor chip, the electrode surfaces were cleaned by employing nitrogen plasma [29,30]. A 2 mM concentration of MUDA was used to prepare the thiol solution in absolute ethanol for SAM deposition [18]. The sensor chips were immersed in the ethanolic solution for overnight followed by washing with ethanol and Milli-Q water, respectively. Later on the sensor chips were dried thoroughly under a stream of nitrogen gas, vacuum-packed, and stored at $+4{ }^{\circ} \mathrm{C}$ till use.

\subsection{Selection of HRP Concentration for Bioassays}

Different concentrations of HRP were initially measured using MiSens device (TUBITAK-BILGEM, Kocaeli, Turkey) to determine the optimum HRP amount for bioassays. For this, six different concentrations of HRP were mixed with same amount of TMB and injected to the MUDA coated surfaces. These optimization experiments were repeated three times and the optimum HRP concentration was chosen based on the average sensor signals.

\subsection{Characterization of SAM Coated Sensor Chips Using AFM}

The bare gold, the SAM coated and the antibody immobilized sensor chips were visualized by employing a Naio (Nanosurf AG, Liestal, Switzerland) atomic force microscope (AFM). Commercially available AFM probes (NCLR) from NanoWorld (NanoWorld AG, Liestal, Switzerland) were used for AFM measurements. The AFM analyses for the SAM-deposited surface and the antibody immobilization were carried out after having completed three cycles of buffer wash flow. The sensor surfaces during the DNA assays were also visualized using AFM. Hence, the NA immobilization, the capturing of DNA surface probe on the NA layer, and the target DNA binding were confirmed. The chips were undocked from the MiSens sensor after three cycles of buffer flow, dried using a gentle nitrogen stream, and then immediately placed in a glass Petri dish. All AFM measurements were performed at room temperature using the intermittent air mode.

\subsection{Development of the Antibody Biosensor}

Two different antibody sensors were developed in this work by using a monoclonal primary antibody and a secondary polyclonal antibody for Salmonella. The primary antibody was used as a surface ligand to specifically capture Salmonella bacterium, whereas the polyclonal antibody was utilized as a detector antibody to increase the sensor signal. Two different bio-detection assays were established: a standard sandwich assay (Scheme 1) and a nanoparticle enhanced sensor assay (Scheme 2). In the latter case the polyclonal antibodies were initially conjugated with gold nanoparticles prior to the Salmonella detection assay.

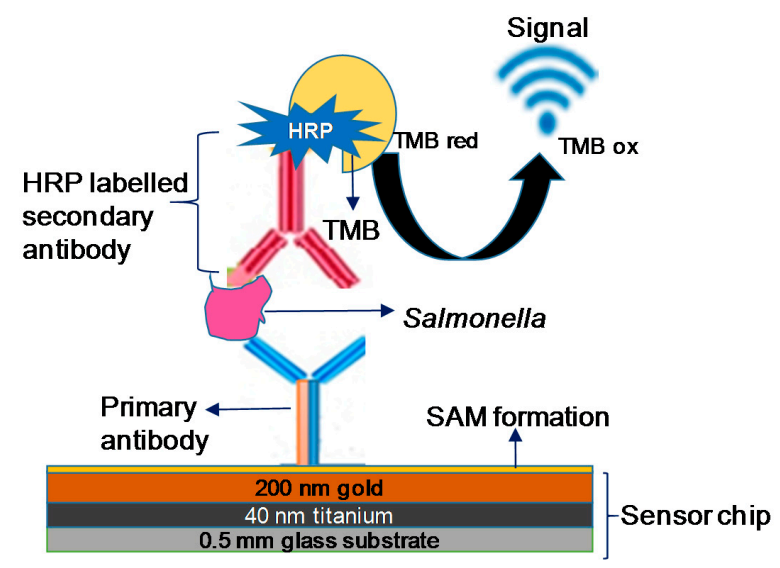

Scheme 1. Principle of antibody sensor development for Salmonella detection using the standard assay. 


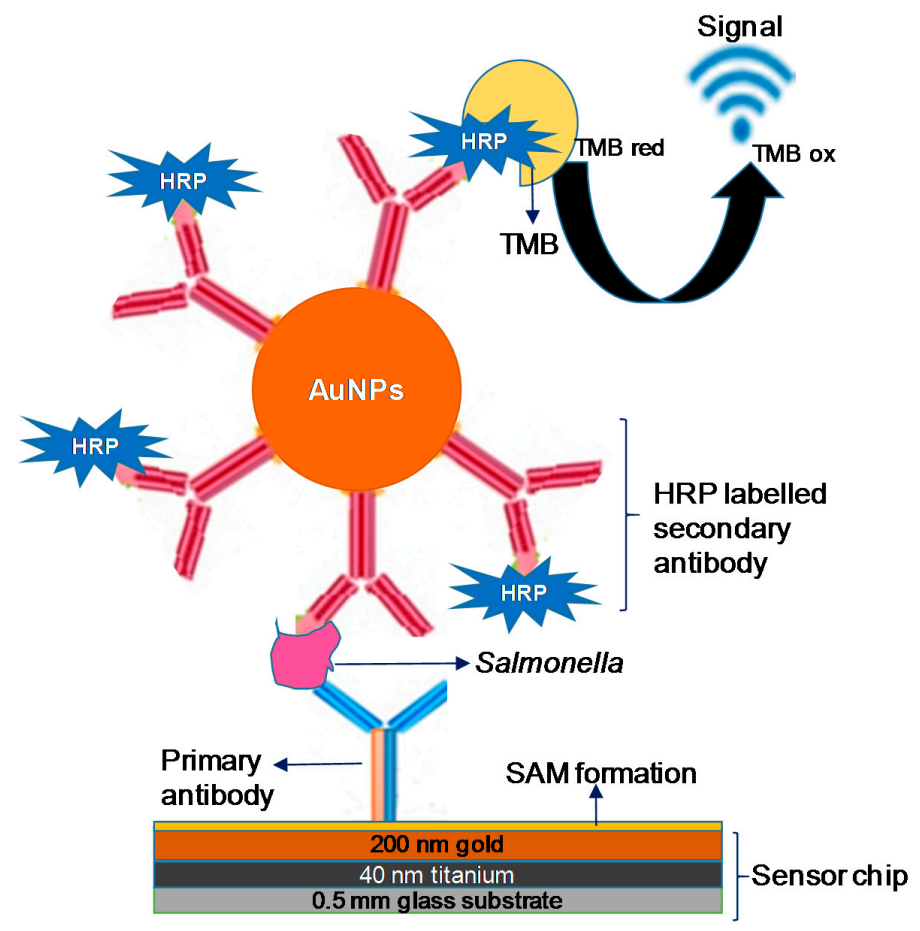

Scheme 2. Principle of the gold nanoparticles enhanced immunosensor for Salmonella detection.

The running buffer used for immobilization was degassed buffered saline (PBS, pH 7.4) and this buffer continuously flowed over the Au sensor surfaces between the injections. The flow rate of the buffer/reagents for the assay was $50 \mu \mathrm{L} \mathrm{min}^{-1}$ unless written otherwise. For the assays, the SAM deposited sensor chip was initially inserted to the device and primed with the running buffer (PBS). The sensor surface was activated with a mixture of EDC $(0.4 \mathrm{M})$ and NHS $(0.1 \mathrm{M})$ in a 1:1 volume ratio by 4 min injection prior to the covalent immobilization of the primary antibody $\left(50 \mu \mathrm{g} \mathrm{mL}^{-1}\right.$, prepared in NaAc buffer, $\mathrm{pH}: 4.5)$ during the $4 \mathrm{~min}$ injection $\left(50 \mu \mathrm{L} \mathrm{min}^{-1}, 200 \mu \mathrm{L}\right)$. The antibody-free areas of the sensing surface were then blocked using a $100 \mu \mathrm{g} \mathrm{mL} \mathrm{m}^{-1} \mathrm{BSA}$ solution $\left(50 \mu \mathrm{L} \mathrm{min}{ }^{-1}, 200 \mu \mathrm{L}\right)$

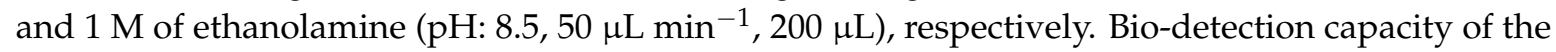
sensor was tested in the investigation range of $1-5.41 \times 10^{7} \mathrm{cfu} \mathrm{mL}^{-1}$ using two different Salmonella sample sources: commercially available $S$. typhimurium and real $S$. typhimurium samples from human stool. The samples were prepared in a particular PBS buffer containing $200 \mu \mathrm{g} \mathrm{mL}^{-1}$ BSA, $0.5 \mathrm{M}$ $\mathrm{NaCl}, 500 \mu \mathrm{g} \mathrm{mL}^{-1}$ dextran, and $0.5 \%$ Tween 20 . Each sample was injected to the sensor surface $\left(50 \mu \mathrm{L} \mathrm{min}{ }^{-1}, 200 \mu \mathrm{L}\right)$ followed by the injection of the HRP-labelled secondary antibody (50 $\mu \mathrm{L} \mathrm{min}-1$, $200 \mu \mathrm{L}$ ). Amperometric measurements were then carried out at $-0.1 \mathrm{~V}$ using TMB reagent $(4 \mathrm{~min}$, $\left.50 \mu \mathrm{L} \mathrm{min}{ }^{-1}\right)$ followed by buffer injection $\left(4 \mathrm{~min}, 100 \mu \mathrm{L} \mathrm{min}{ }^{-1}\right)$. The sensor surface regeneration was achieved with the injection of $0.1 \mathrm{M} \mathrm{HCl}\left(1 \mathrm{~min}, 100 \mu \mathrm{L} \mathrm{min}^{-1}\right)$ twice for the sequential detection of different Salmonella concentrations.

The gold nanoparticle-enhanced bioassays (Scheme 2) were performed using the same procedure. In this case, the HRP-labelled secondary antibody was conjugated with AuNPs prior to the experiments to amplify the sensor signal. The AuNP conjugation protocol was described in our earlier studies [18] and used as is in this work. The secondary antibody-labelled AuNPs were stored at $+4{ }^{\circ} \mathrm{C}$ and warmed to room temperature before use. The concentration of nanoparticles was calculated at $525 \mathrm{~nm}$ wavelength and the AuNP solution was diluted based on the dilution factor calculated by considering the OD value. Commercially available S. typhimurium and real S. typhimurium samples from human stool were detected in a concentration range from 1 to $5.41 \times 10^{7} \mathrm{cfu} \mathrm{mL}^{-1}$ using the amperometric sensor. 


\subsection{Development of the DNA Biosensor}

\subsubsection{Immobilization of Neutravidin and DNA Capture Probe on the Sensor Chip Surface}

The SAM formation was initially performed on the sensor chip using 2 mM MUDA as described in Section 2.4. The chip and the PMMA cassette were then assembled together using a double-sided sticky tape and docked to the sensor device that was primed with degassed Dulbecco's modified phosphate-buffered saline (PBS, pH: 7.4). The same reagent was used as the running buffer during NA immobilization and continuously flowed over the sensor surfaces between the injections. The flow rate of the sensor was $50 \mu \mathrm{L} \mathrm{min}{ }^{-1}$ during the DNA bioassays unless written otherwise. The SAM-coated electrode surfaces of the sensor chip were activated using amine coupling chemistry [29,31]. For this, a mixture of EDC (0.4 M)-NHS $(0.1 \mathrm{M})$ at 1:1 volume ratio was injected to the surface during $4 \mathrm{~min}$. The NA prepared in PBS $\left(50 \mu \mathrm{g} \mathrm{mL}^{-1}, 250 \mu \mathrm{L}\right)$ was then immobilized to the sensor surface followed by the injection of ethanolamine $\left(1 \mathrm{M}, 250 \mu \mathrm{L}^{-1} \mathrm{pH}\right.$ : 8.5) for blocking of the NA-free areas on the surface [31]. After immobilization of NA, the running buffer was changed to Tris buffer (20 mM Tris-HCI, $150 \mathrm{mM} \mathrm{NaCl}$, and $1 \mathrm{mM}$ EDTA, pH: 7.0) and it was used during the capturing of the biotinylated complementary surface probe and the detection of Salmonella DNA. The surface probe was prepared in Tris buffer in the concentration of $10 \mu \mathrm{M}$ and injected to the NA-immobilized surface for $5 \mathrm{~min}$, followed by a $1 \mathrm{~min}$ injection of $10 \mathrm{mM}$ biotin to block the remaining active sites of the NA surface. To obtain a control surface, a biotinylated non-specific surface probe was captured on the NA layer and used for the target detection assays. The sensor signals obtained upon the binding of Salmonella DNA on the non-specific surfaces were subtracted from the results obtained on the target specific surfaces.

\subsubsection{Preparation of HRP-NA-Labelled AuNPs}

The HRP-NA labelled AuNPs were used for the sensitive detection of the target DNA. In this assay, $\mathrm{HRP}$ is required to convert $\mathrm{TMB}_{\text {red }}$ to $\mathrm{TMB}_{\mathrm{ox}}$, and produce a measurement signal using the amperometric sensor (Scheme 3). It was well defined that proteins can physically bind to the gold surface via electrostatic interactions [32]. Herein, the same approach was used for modification of AuNPs with HRP and NA. For this, a $1 \mathrm{~mL}$ solution of the gold nanoparticles $(15 \mathrm{~nm})$ was derivatised with NA $\left(1.5 \mu \mathrm{L}, 1 \mathrm{mg} \mathrm{mL}^{-1}\right)$ and $\operatorname{HRP}\left(2.5 \mu \mathrm{L}, 1 \mathrm{mg} \mathrm{mL}^{-1}\right)$ in an Eppendorf tube that was covered by aluminum foil to prevent exposure to light. This solution was incubated for $45 \mathrm{~min}$ on a shaker at room temperature prior to centrifugation for discarding excess reagents. The supernatant was removed, and $30 \mu \mathrm{L}$ of BSA $\left(10 \mathrm{mg} \mathrm{mL}^{-1}\right)$ and $100 \mu \mathrm{L}$ Tris buffer $(20 \mathrm{mM})$ were added to the tube, respectively. The modified AuNPs were stored at $+4{ }^{\circ} \mathrm{C}$ until use. The AuNP concentration was determined using a spectrophotometer at a wavelength of $525 \mathrm{~nm}$.

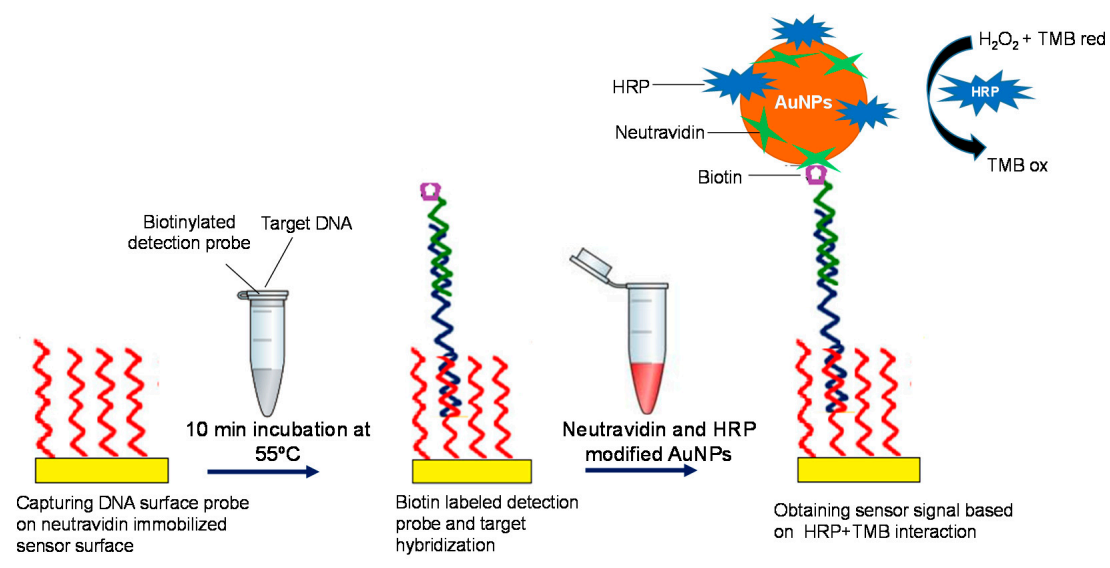

Scheme 3. Principle of the DNA assay using the microfluidic-based electrochemical biosensor. 


\subsubsection{DNA Detection Assay}

Specific gene for Salmonella spp. was selected based on the literature [33]. For DNA assays, the biotinylated surface probe was initially captured by the NA immobilized surface. The concentrations of capture $(10 \mu \mathrm{M})$ and detection $(10 \mu \mathrm{M})$ probes were kept the same for all experiments. The biotin-free Salmonella DNA was incubated with the biotinylated detection probe for $10 \mathrm{~min}$ at $55^{\circ} \mathrm{C}$ using a thermal cycler. The hybridized DNA molecules were then injected to the sensor surface during $5 \mathrm{~min}(250 \mu \mathrm{L})$ followed by the injection of the HRP-NA modified AuNPs for 4 min $(200 \mu \mathrm{L})$. The modified AuNPs bound to the sensor surface via interaction between the biotin label of the detection probe and the NA label of the AuNPs. The electrochemical signal was obtained using a real-time electrochemical profiling $^{\mathrm{TM}}$ (REP ${ }^{\mathrm{TM}}$, TUBITAK-BILGEM, Kocaeli, Turkey) assay at a fixed potential of $-0.1 \mathrm{~V}$ and the current was measured continuously. The current values were recorded during Tris buffer injection and this signal was considered as a baseline. The subsequent injection of $200 \mu \mathrm{L}$ TMB revealed a current change and the subtraction between the current obtained during TMB and buffer was used as the sensor signal (Figure 2).

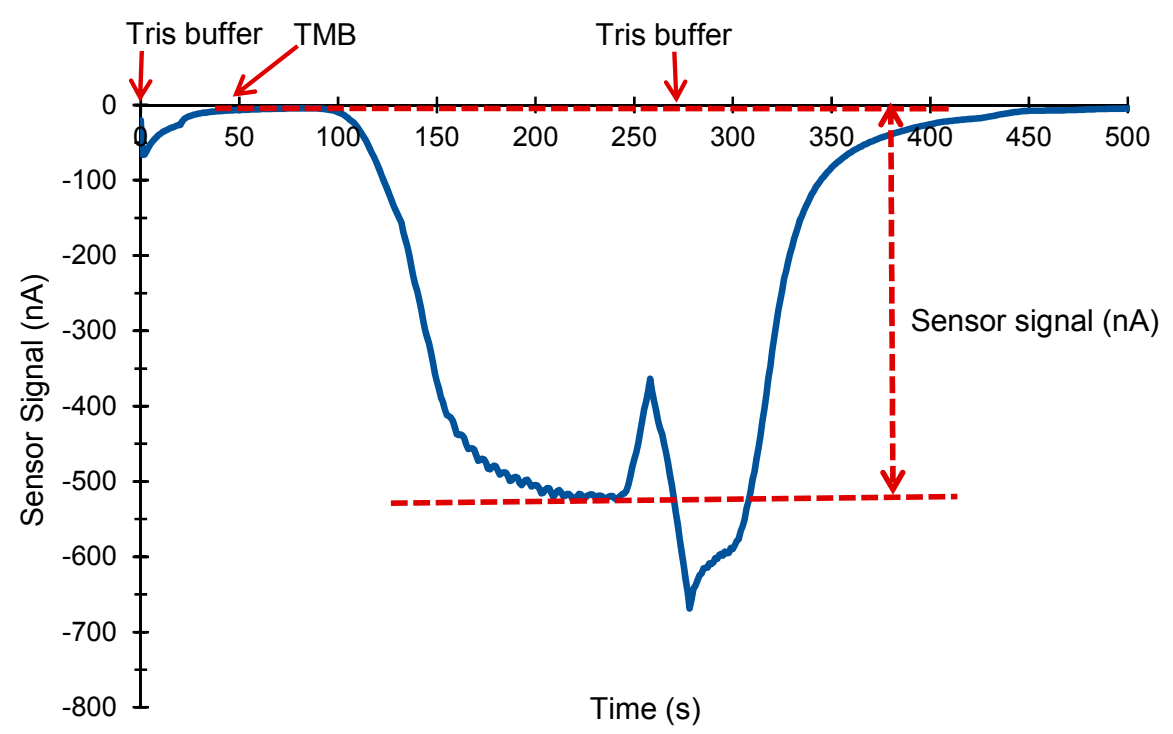

Figure 2. The current response of an individual electrode at $-0.1 \mathrm{~V}$ potential is recorded uninterruptedly during the consequent injections of buffer and TMB substrate to the HRP-bound electrode to obtain a sensorgram. The flow rate of the device is $50 \mu \mathrm{L} \mathrm{min}{ }^{-1}$ during the injections.

\section{Results and Discussion}

\subsection{Antibody Sensor for Salmonella Detection}

Prior to developing the bioassays, we initially investigated the optimum HRP concentration for use in electrochemical sensor. The sensor signal gradually increased from $1.5 \mathrm{ng} \mathrm{mL}^{-1}$ to $12 \mathrm{ng} \mathrm{mL}^{-1}$ of HRP, whereas it showed a clear decrease afterwards (Figure 3). Hence, $12 \mathrm{ng} \mathrm{mL}^{-1}$ was selected as the optimum concentration for HRP and used for the entire study. 


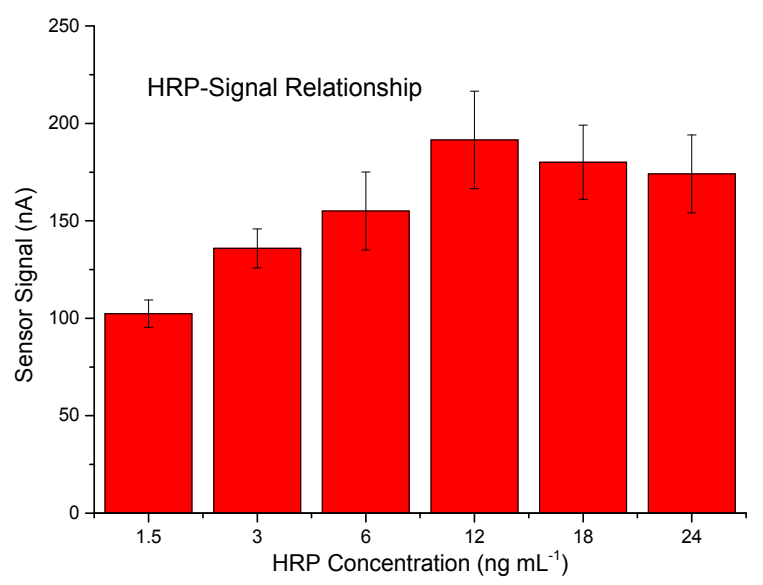

(A)

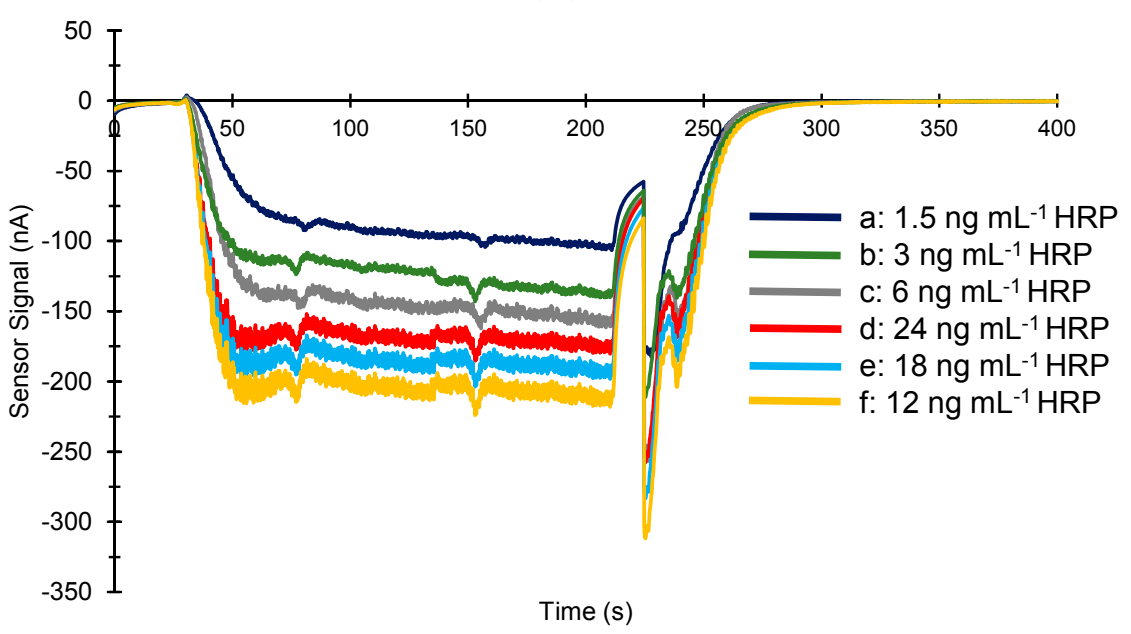

(B)

Figure 3. Overall results of HRP-TMB optimization assays in a concentration range of $1.5-24 \mathrm{ng} \mathrm{mL}^{-1}$ (A) and real-time sensorgrams obtained with six different HRP concentrations (B).

\subsubsection{Standard Sandwich Assay for the Analysis of Commercial and Real Samples}

The initial investigations were carried out with commercially available Salmonella typhimurium samples using a standard sandwich assay. The bare, the SAM-coated, and the antibody-immobilized sensor surfaces were characterized by AFM (Figure 4). The 3D surface topology images in $1 \times 1 \mu \mathrm{m}$ scanning area resulted in the heights of $11.5 \mathrm{~nm}, 12.3 \mathrm{~nm}, 22 \mathrm{~nm}$ for bare (Figure 4A), MUDA-coated (Figure 4B), and antibody-immobilized (Figure 4C) surfaces, respectively. The gradual increase of the surface height confirmed the successful preparation of the sensor chip for bacteria detection assays. 

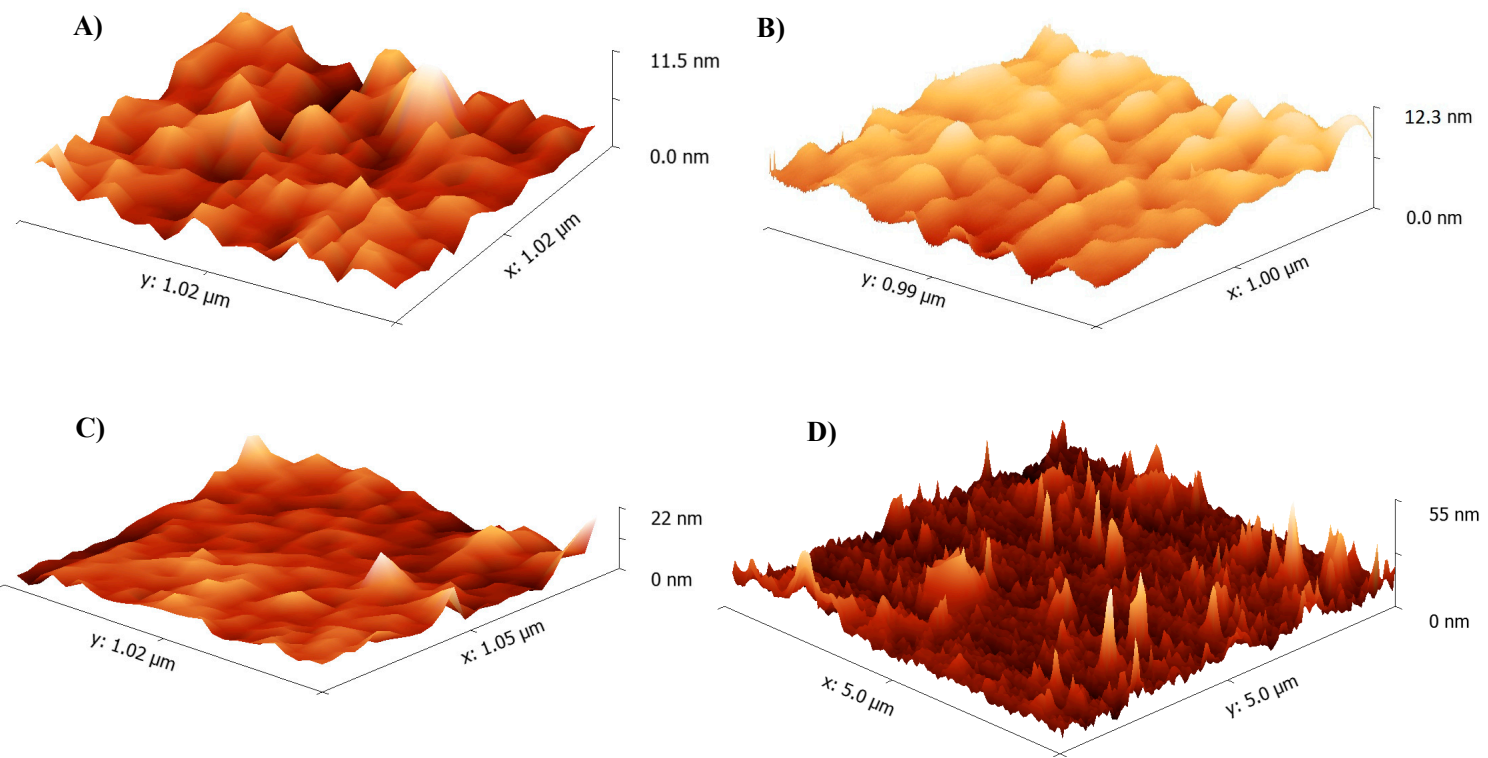

Figure 4. AFM analysis of bare (A), MUDA-coated (B) and antibody-immobilized (C,D) sensor surfaces.

Salmonella detection was investigated in the concentration range of $1-5.41 \times 10^{7} \mathrm{cfu} \mathrm{mL}^{-1}$, which provided a limit of detection (LOD) of $2.7 \times 10^{1} \mathrm{cfu} \mathrm{mL}^{-1}$ for both commercial and real samples. The average signal ratio in the entire concentration range between commercial and real sample analyses was determined as 1.1. The overall results of Salmonella detection were subjected to the logarithmic regression analysis that resulted in the correlation coefficients of 0.9671 and 0.9505 for commercial and real samples, respectively (Figure 5).

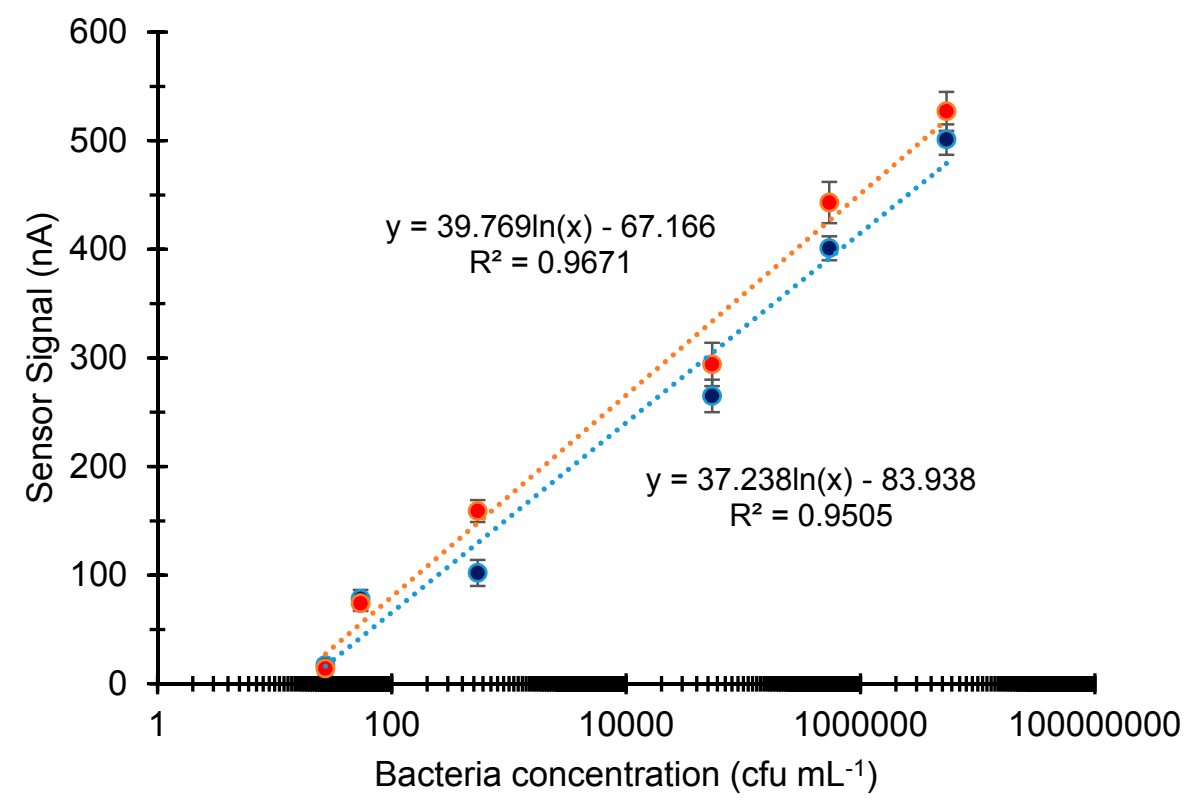

- Real samples - Commercial samples

Figure 5. Overall results of Salmonella detection in a concentration range of $27-5.41 \times 10^{7}$ using a standard sandwich assay $(n=6)$. 


\subsubsection{Nanoparticle Enhanced Sandwich Assay for the Analysis of Commercial and Real Samples}

The use of nanomaterials significantly enhanced the sensor signal and allows detecting trace amounts of pathogens that has critical role in diagnostic [11]. To obtain a more sensitive diagnostic assay for Salmonella detection we, therefore, used the AuNP-modified sandwich assay. The sensor signal obtained with AuNP conjugated detector antibody is proportional to the amount of bacteria captured on the surface by the primary antibody. The commercial and real Salmonella samples were investigated in a concentration range of $1-5.41 \times 10^{7} \mathrm{cfu} \mathrm{mL}^{-1}$ (Figure 6A), which resulted in a $1 \mathrm{cfu} \mathrm{mL}^{-1} \mathrm{LOD}$ (Figure 6A,B). The logarithmic regression analysis of all results revealed a good reproducibility for the assays with correlation coefficients of 0.9931 and 0.9902 for commercial and real sample analysis, respectively (Figure 6C). The signal ratio between the two assays was calculated based on the detection limit responses of two assays and it was found to be 1.098. In the entire investigation range, the average signal ratio of commercial sample analysis to real sample analysis was found to be 1.03. Therefore, for the first time in this study, we demonstrated that the sensor can reliably measure Salmonella samples from different sources with a very high accuracy. Additionally, 50 times higher sensitivity was obtained in this work when compared to our earlier work [18] and this is most likely due to the new chip design.

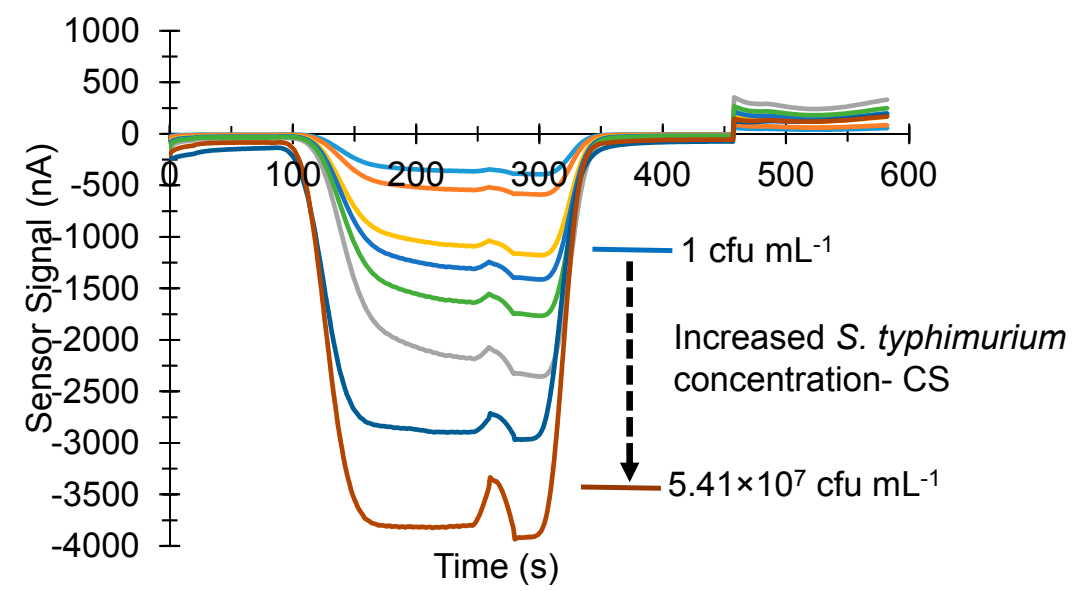

(A)

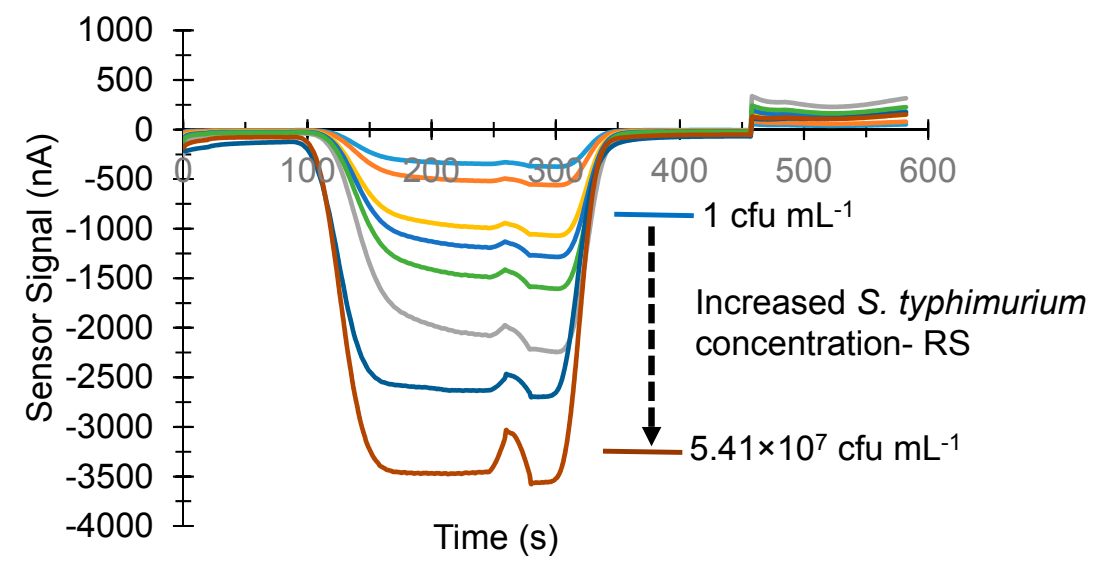

(B)

Figure 6. Cont. 


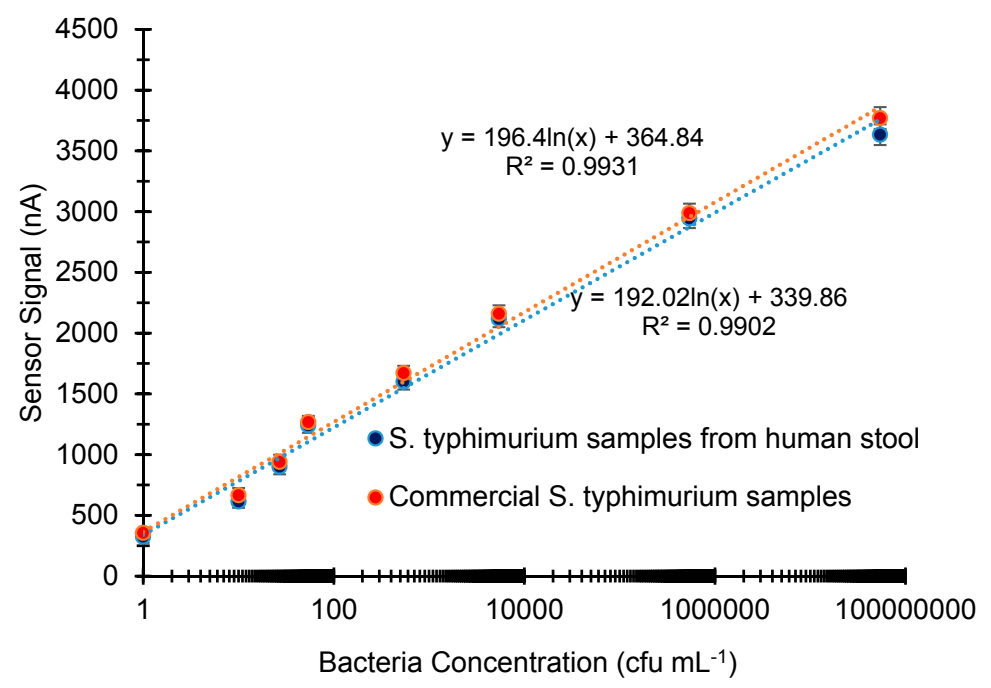

(C)

Figure 6. Real-time sensorgrams of commercial (A) and real S. typhimurium (B) detection in a concentration range of $1-5.41 \times 10^{7} \mathrm{cfu} \mathrm{mL}^{-1}$. Overall results of the AuNP-enhanced sandwich assays for the determination of commercial and real samples $(n=6)(C)$. CS: commercial sample, RS: real sample.

Liebana et al. investigated Salmonella detection in milk using an electrochemical magnetoimmunosensor where the bacteria were captured and preconcentrated from milk samples by utilizing magnetic beads via an immunological interaction [24]. A limit of detection of $7.5 \times 10^{3} \mathrm{cfu} \mathrm{mL}^{-1}$ in milk diluted 1/10 in lysogeny broth was achieved in 50 min without any pretreatment. Another magnetoimmunosensor for Salmonella quantification was reported using nano- and micro-sized magnetic particles that allowed measuring S. enterica down to $5 \times 10^{4}$ and $1 \times 10^{4} \mathrm{cfu} \mathrm{mL}^{-1}$, respectively [15]. A disposable immunosensor, combining a permanent magnet under the screen-printed carbon electrode and AuNPs as signal amplification agents, offers an alternative platform for sensitive detection of Salmonella enterica subsp. enterica serovar Typhimurium LT2 (S) [14]. This sensor was able to measure the target bacteria in a linear concentration range from $10^{3}$ to $10^{6} \mathrm{cfu} \mathrm{mL}^{-1}$ with a detection limit of $143 \mathrm{cfu} \mathrm{mL}^{-1}$. The AuNP enhanced biosensor technique combined with magnetic field application provided more sensitive detection platform than the conventional commercial method carried out for comparison purposes. The total sensor assay time using the disposable immunosensor was 1:30 h per sample [14]. Electrochemical sensing of Salmonella typhimurium in milk samples was investigated using iron oxide/gold core/shell nanomagnetic probes and CdS biolabels [21]. The screen-printed carbon electrodes were used as the sensor substrate and the measurements were carried out by square-wave anodic stripping voltammetry through the use of CdS nanocrystals. The bacterium was measured between $1 \times 10^{1}$ and $1 \times 10^{6} \mathrm{cfu} \mathrm{mL}^{-1}$, and a LOD of $13 \mathrm{cfu} \mathrm{mL}{ }^{-1}$ was recorded. The determination of Salmonella in milk samples using the biosensor required less than $1 \mathrm{~h}$ [21]. On the other hand, the AuNP modified sandwich assay in our work could detect S. typhimurium in a concentration range of $1-5.41 \times 10^{7}$ with LOD of $1 \mathrm{cfu} \mathrm{mL}^{-1}$, which demonstrates much higher sensitivity than all of the reported works. Additionally, the preparation of our antibody sensor required $30 \mathrm{~min}$ and the detection of a sample was achieved in only $12 \mathrm{~min}$. Furthermore, the same sensor surface could be used multiple times in this work, avoiding the preparation of the antibody-immobilized surface all the time. The reliability and accuracy of the sensor are also very high, which could be demonstrated by studying with different sample sources.

\subsubsection{Cross-Reactivity Studies for Salmonella}

To determine the specificity of the developed assays for the detection of Salmonella, the interaction of non-specific bacteria with the Salmonella-specific antibody-immobilized surfaces was studied. 
S. typhimurium was used as the target bacterium, whereas S. aureus and E. coli were investigated as the non-specific bacteria. Being a Salmonella serotype the binding of S. enteritidis on the antibody immobilized surface was also tested. A fixed concentration $\left(10^{7} \mathrm{cfu} \mathrm{mL} \mathrm{m}^{-1}\right)$ of each bacterium was used for cross-reactivity tests. The non-specific binding responses of $S$. aureus and E. coli were calculated as $2.66 \%$ and $2.01 \%$, respectively, suggesting the high specificity of the bioassay for Salmonella (Figure 7). The binding of $S$. enteritidis on the Salmonella antibody immobilized surface was determined as $14.35 \%$. Nevertheless, the specificity of antibody sensors for bacteria is often a problem, which motivated us to develop a DNA biosensor in this work as an alternative method.

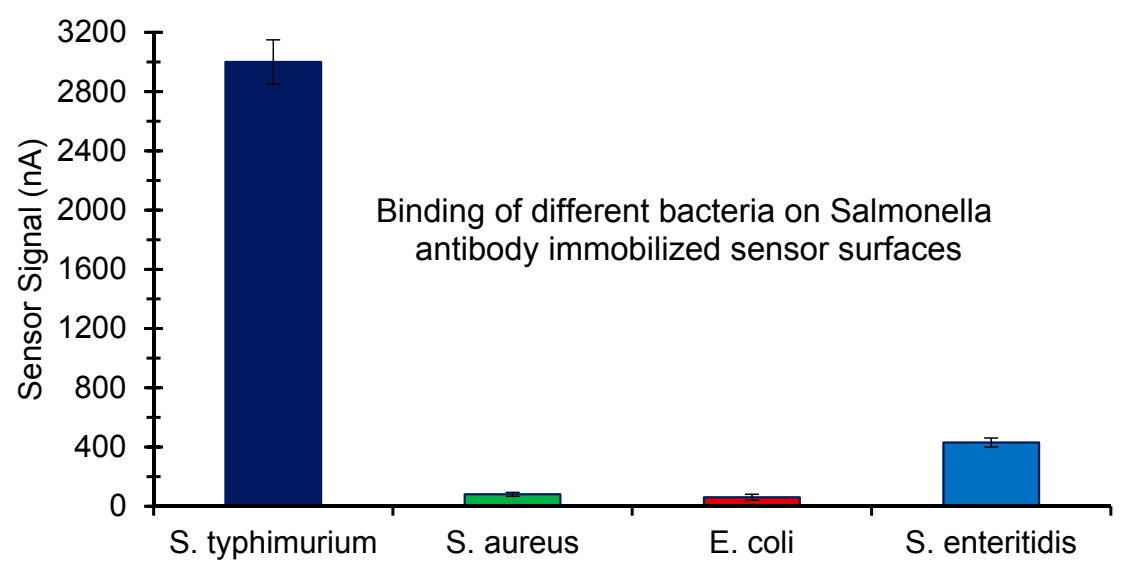

Figure 7. Cross-reactivity tests for S. typhimurium specific antibody sensor assay $(\mathrm{n}=3)$.

\subsection{DNA Sensor for Salmonella Detection}

For the first time, we investigated the potential of our custom-designed MiSens device for the development of a DNA biosensor for pathogenic bacteria detection in this study. The detection of target Salmonella DNA was studied in a concentration range of $0.002-200 \mu \mathrm{M}$ using the DNA surface probe that was initially captured by a neutravidin-immobilized layer on the sensor chip (Figure 8A). The sensor could differentiate the lowest concentration of DNA (0.002) and negative control (Figure 8B) and showed a good reproducibility in a wide investigation range (Figure 8C). The LOD was verified based on the linear portion of the saturation graph by calculating three times the standard deviation of the blank response $(0.4 \times 3=1.2 \mathrm{nA})$ and extrapolating the sensor signal in the linear calibration curve to convert the value to concentration [34]. The limit of detection was determined to be $0.94 \mathrm{nM}$ with a linear range from 2 to $20 \mathrm{nM}$, as shown in Figure 8D.

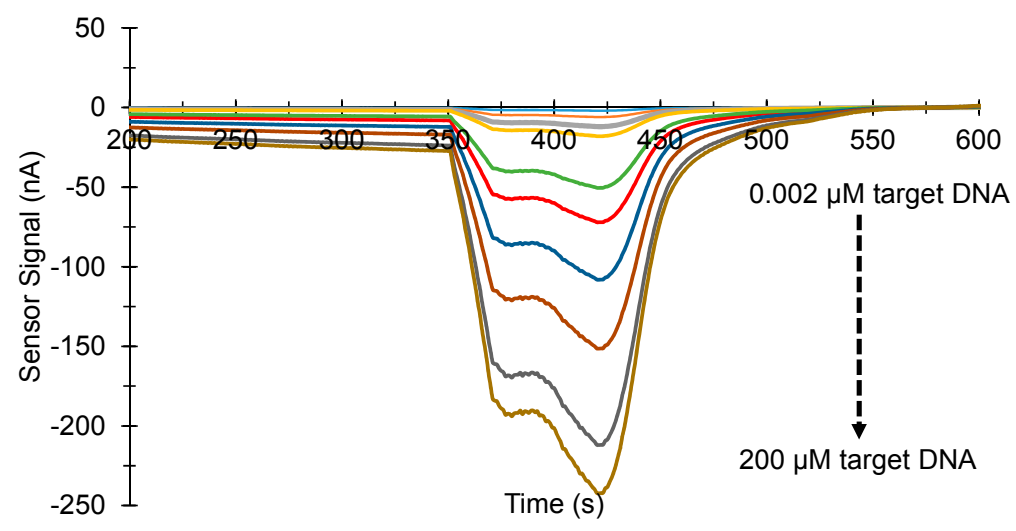

(A)

Figure 8. Cont. 


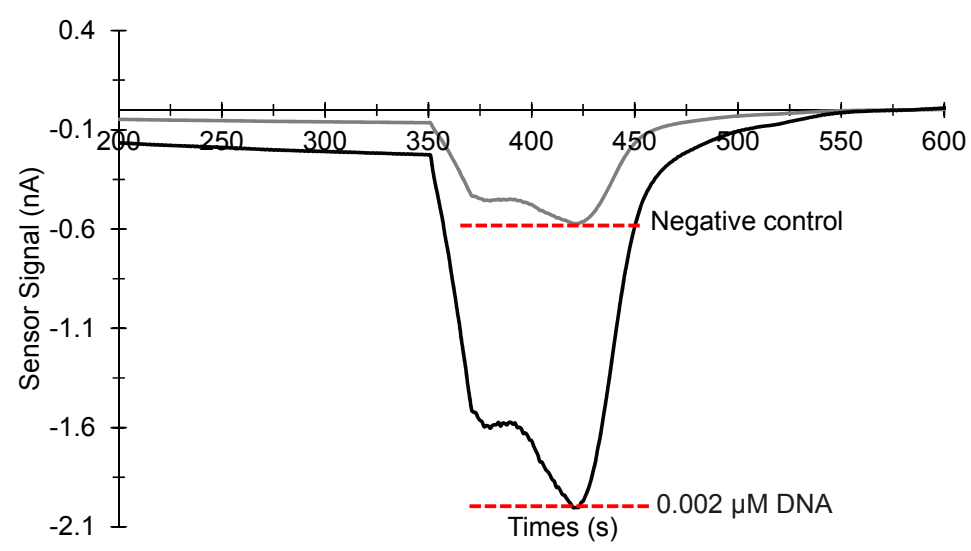

(B)

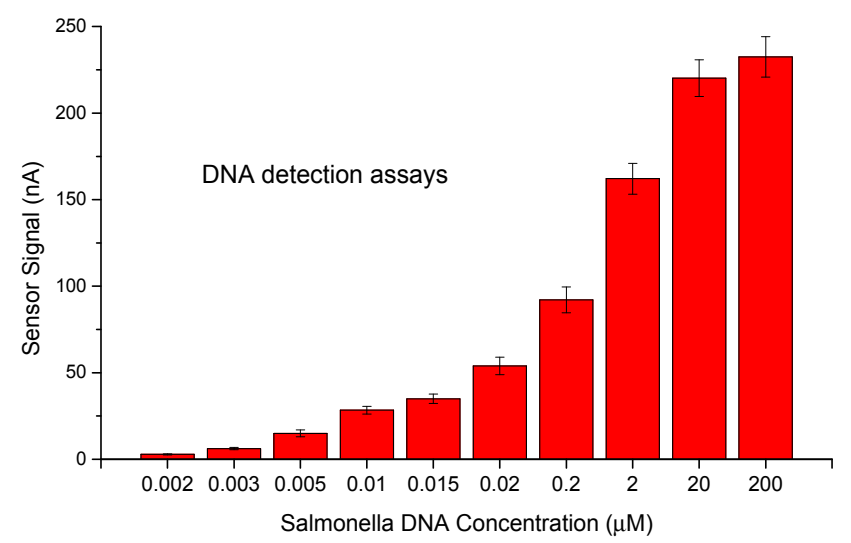

(C)

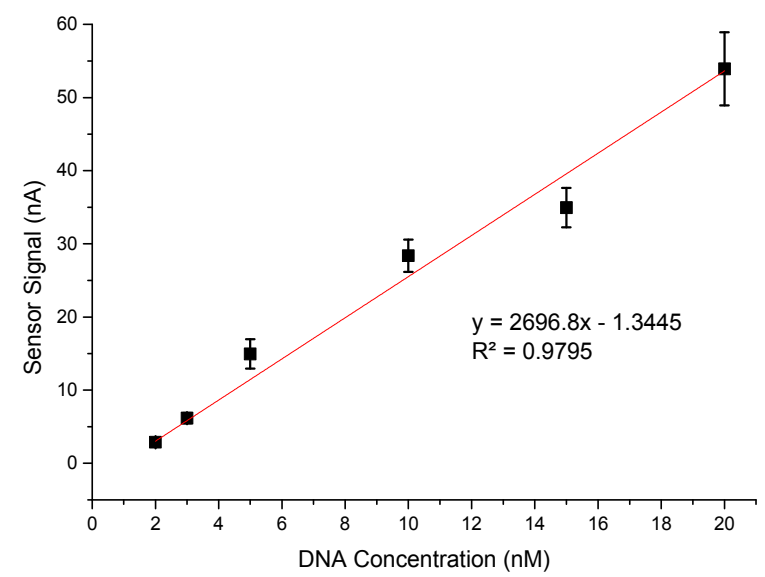

(D)

Figure 8. Concentration-dependent real-time sensorgram of the DNA assay (A). Real-time sensorgram showing signal difference between the lowest DNA concentration and negative control (B). The detection of Salmonella DNA in a concentration range of 0.002-200 $\mu \mathrm{M}$ along with standard deviations on the data $(n=6)(C)$. The linear calibration curve of DNA assays with a correlation coefficient of 0.9795 (D).

Every step of the DNA assay was characterized by employing AFM. The 2D height images and the 3D surface topography images were analyzed in the scanning area of $3 \times 3 \mu \mathrm{m}$ (Figure 9). 
A clear difference in height was observed between MUDA-coated (12.3 nm) and the NA immobilized $(21 \mathrm{~nm})$ sensor surfaces, indicating the effective NA immobilization for the DNA surface probe capture. When the surface probe was captured by the NA layer, a further increase in height (26 nm) was observed and the 3D surface topology image also displayed a rougher surface than that of the NA immobilization. Upon binding of the target DNA on the surface, the height reached $31 \mathrm{~nm}$ and the surface roughness significantly increased.

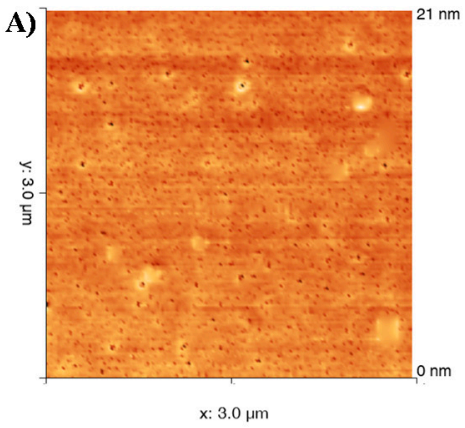

B)

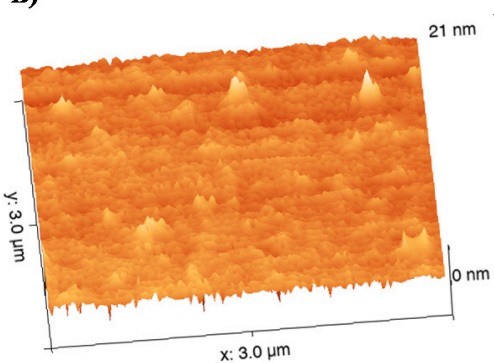

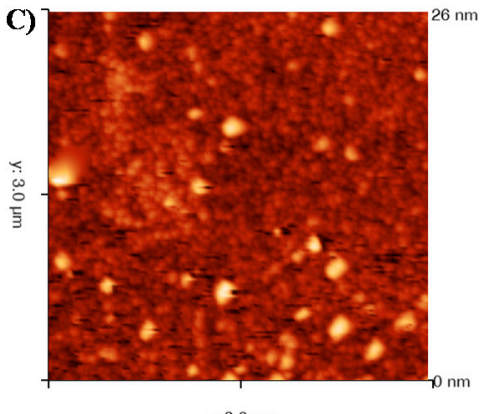

$\mathrm{x}: 3.0 \mu \mathrm{m}$

D)

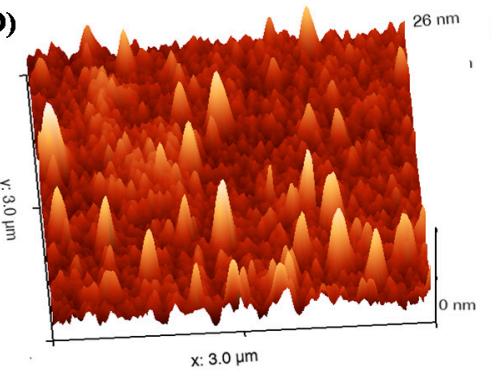

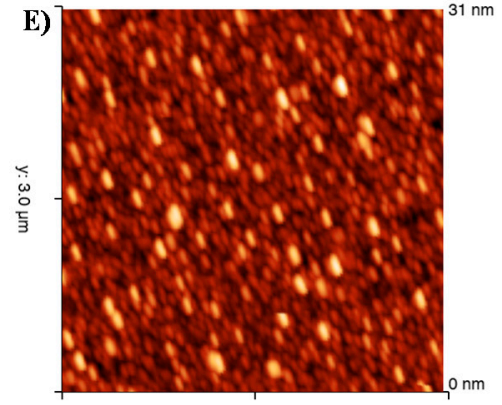

$x: 3.0 \mu \mathrm{m}$

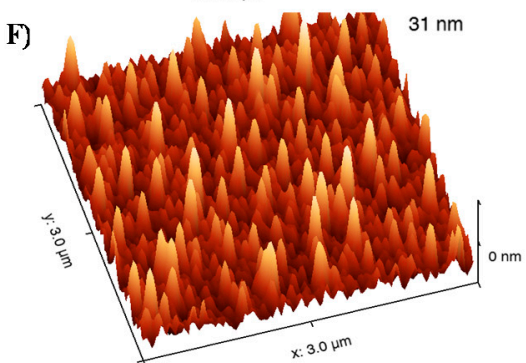

Figure 9. AFM 2D height images (upper part) and 3D topography images (lower part) of neutravidin immobilization (A,B), DNA surface probe capture $(\mathbf{C}, \mathbf{D})$, and target DNA binding at $2 \mu \mathrm{M}$ concentration $(\mathbf{E}, \mathbf{F})$.

DNA biosensors constitute strong alternatives to the antibody sensors for diagnosis of pathogenic bacteria by quantifying the genetic material of a bacterium of interest. A disposable electrochemical sensor developed for Salmonella detection based on a DNA hybridization reaction using the thiolated DNA capture probes could quantify Salmonella DNA from $5 \mu \mathrm{M}$ to $20 \mu \mathrm{M}$. The hybridization event was detected using the ruthenium complex as electrochemical indicator. The sensor demonstrated high selectivity towards Salmonella when compared to E. coli [35]. The DNA sensor constructed in the current study detected Salmonella DNA down to $0.002 \mu \mathrm{M}$, which displays enormously higher sensitivity than the disposable electrochemical sensor. However, it is worth mentioning that we have not tested the sensor against other non-specific bacteria species in this work as the main focus of the current study was to investigate the potential of our custom-designed sensor for the construction of DNA assays for pathogenic bacteria detection. Instead, the specificity of the DNA assays was checked using the control surface probe and no signal was observed upon the target injection to the sensor.

Zhang et al. used the biotinylated single-stranded DNA capture probe, immobilized onto a streptavidin-coated dextran sensor surface, to detect a specific sequence in the invA gene of Salmonella by employing a label-free SPR biosensor (i.e., Biacore $\mathrm{X}^{\mathrm{TM}}$, BIAcore AB). The target DNA could be measured in the range of $5-1000 \mathrm{nM}$ with a detection limit of $0.5 \mathrm{nM}$. This sensor was used for the detection of single-stranded invA amplicons from three serovars of Salmonella, including Typhimurium, Enterica, and Derby, and the responses to PCR products were related to different $S$. typhimurium concentrations in the range of $10^{2}-10^{10} \mathrm{cfu} \mathrm{mL}^{-1}$. The hybridization reaction using the SPR sensor required $15 \mathrm{~min}$, whereas the electrochemical sensor in this work allowed the DNA hybridization only in 5 min. The surface regeneration could be achieved in both studies for multiple usage of the same chip using glycine-HCI 
(10 mM, pH: 3.0) [36] and HCI (100 mM, pH: 3), respectively. The use of gold nanoparticles in the DNA sensor development offers superior sensitivities that play a crucial role while working with interfering media, such as milk and blood. The DNA sensors employing AuNP functionalized probes can quantify trace levels of Salmonella (for e.g., $6 \mathrm{cfu} \mathrm{mL}^{-1}$ ) in such complex sample media [20]. The AuNP-enhanced DNA biosensor in this work shows great potential for Salmonella detection and our future direction will be the further characterization of the developed sensor to be used in complex samples that may have a significant impact in clinical diagnosis, environmental monitoring, and food safety.

\section{Conclusions}

In this work, antibody and DNA-based biosensors were developed using a fully-automated custom-designed microfluidic device. Two different antibody biosensors were constructed using standard and nanomaterial-enhanced assay approaches. The nanomaterial-enhanced immunosensor (LOD: $1 \mathrm{cfu} \mathrm{mL}^{-1}$ ) increased the limit of detection around 27-fold when compared to the standard sandwich assay (LOD: $27 \mathrm{cfu} \mathrm{mL}^{-1}$ ) for Salmonella determination from human stool samples. On the other hand, the potential of the microfluidic sensor for the DNA analysis of pathogenic bacteria was successfully demonstrated for the first time. The developed DNA biosensor could detect the Salmonella DNA in a wide concentration range of $0.002-200 \mu \mathrm{M}$ with a LOD of $0.94 \mathrm{nM}$. Both antibody and DNA biosensors have shown high sensitivity and specificity for Salmonella samples. The sensor surface could be regenerated multiple times in all assay types, which significantly reduces the cost of the system, as well as the required analysis time by skipping the receptor immobilization step. The developed sensors can be used for the diagnosis of infectious diseases caused by pathogenic bacteria.

Author Contributions: S.S. performed the experiments. S.S. and Z.A. analyzed the data. A.E. and Y.G. contributed to the sensor chip fabrication. B.L. and S.K. provided the microbiology facilities. Z.A. supervised the research, directed the project, and prepared the manuscript.

Funding: The authors would like to thank TUBITAK-BİLGEM for supporting this work. Z.A. acknowledges additionally the support of the European Union (10041380) and the Marie Curie Actions.

Conflicts of Interest: The authors declare no conflict of interest.

\section{References}

1. Liu, X.; Hu, Y.X.; Zheng, S.; Liu, Y.; He, Z.; Luo, F. Surface plasmon resonance immunosensor for fast, highly sensitive, and in situ detection of the magnetic nanoparticles-enriched Salmonella enteritidis. Sens. Actuators B Chem. 2016, 230, 191-198. [CrossRef]

2. Centers for Disease Control and Prevention. National Enteric Disease Surveillance: Salmonella Annual Report; National Center for Emerging and Zoonotic Infectious Diseases, Division of Foodborne W, and Environmental Diseases: Atlanta, GA, USA, 2012.

3. European Food Safety Authority (EFSA). EFSA Explains Zoonotic Diseases; EFSA: Parma, Italy, 2014.

4. Ozdemir, K.; Acar, S. Plasmid profile and pulsed-field gel electrophoresis analysis of Salmonella enterica isolates from humans in Turkey. PLoS ONE 2014, 9, e95976. [CrossRef] [PubMed]

5. Cinti, S.; Volpe, G.; Piermarini, S.; Delibato, E.; Palleschi, G. Electrochemical biosensors for rapid detection of foodborne Salmonella: A Critical Overview. Sensors 2017, 17, 1910. [CrossRef] [PubMed]

6. Feder, I.; Nietfeld, J.C.; Galland, J.; Yeary, T.; Sargeant, J.M.; Oberst, R.; Tamplin, M.L. Comparison of cultivation and PCR-hybridization for detection of Salmonella in porcine fecal and water samples. J. Clin. Microbiol. 2001, 39, 2477-2484. [CrossRef] [PubMed]

7. Wang, W.B.; Liu, L.Q.; Song, S.S.; Tang, L.J.; Kuang, H.; Xu, C.L. A highly sensitive ELISA and immunochromatographic strip for the detection of Salmonella typhimurium in milk samples. Sensors 2015, 15, 5281-5292. [CrossRef] [PubMed]

8. Fitzgerald, C.; Sherwood, R.; Gheesling, L.L.; Brenner, F.W.; Fields, P.I. Molecular analysis of the rfb O antigen gene cluster of Salmonella enterica serogroup O:6,14 and development of a serogroup-specific PCR assay. Appl. Environ. Microbiol. 2003, 69, 6099-6105. [CrossRef] [PubMed] 
9. Zhang, Z.; Xiao, L.; Lou, Y.; Jin, M.; Liao, C.; Malakar, P.K.; Pan, Y.; Zhao, Y. Development of a multiplex real-time PCR method for simultaneous detection of Vibrio parahaemolyticus, Listeria monocytogenes and Salmonella spp. in raw shrimp. Food. Control 2015, 51, 31-36. [CrossRef]

10. Maurischat, S.; Baumann, B.; Martin, A.; Malorny, B. Rapid detection and specific differentiation of Salmonella enterica subsp enterica Enteritidis, Typhimurium and its monophasic variant 4,[5], 12:i-By real-time multiplex PCR. Int. J. Food Microbiol. 2015, 193, 8-14. [CrossRef] [PubMed]

11. Altintas, Z. Biosensors and Nanotechnology: Applications in Health Care Diagnostics; Wiley: Hoboken, NJ, USA, 2017; ISBN 978-1-119-06501-2.

12. Sheikhzadeh, E.; Chamsaz, M.; Turner, A.P.F.; Jager, E.W.H.; Beni, V. Label-free impedimetric biosensor for Salmonella Typhimurium detection based on poly pyrrole-co-3-carboxyl-pyrrole copolymer supported aptamer. Biosens. Bioelectron. 2016, 80, 194-200. [CrossRef] [PubMed]

13. Malhotra, R.; Patel, V.; Chikkaveeraiah, B.V.; Munge, B.S.; Cheong, S.C.; Zain, R.B.; Abraham, M.T.; Dey, D.K.; Gutkind, J.S.; Rusling, J.F. Ultrasensitive detection of cancer biomarkers in the clinic by use of a nanostructured microfluidic array. Anal. Chem. 2012, 84, 6249-6255. [CrossRef] [PubMed]

14. Afonso, A.S.; Uliana, C.V.; Martucci, D.H.; Faria, R.C. Simple and rapid fabrication of disposable carbon-based electrochemical cells using an electronic craft cutter for sensor and biosensor applications. Talanta 2016, 146, 381-387. [CrossRef] [PubMed]

15. Sutarlie, L.; Ow, S.Y.; Su, X.D. Nanomaterials-based biosensors for detection of microorganisms and microbial toxins. Biotechnol. J. 2017, 12, 1-25. [CrossRef] [PubMed]

16. Masdor, N.A.; Altintas, Z.; Tothill, I.E. Surface plasmon resonance immunosensor for the detection of Campylobacter jejuni. Chemosensors 2017, 5, 16. [CrossRef]

17. Masdor, N.A.; Altintas, Z.; Tothill, I.E. Sensitive detection of Campylobacter jejuni using nanoparticles enhanced QCM sensor. Biosens. Bioelectron. 2016, 78, 328-336. [CrossRef] [PubMed]

18. Altintas, Z.; Akgun, M.; Kokturk, G.; Uludag, Y. A fully automated microfluidic-based electrochemical sensor for real-time bacteria detection. Biosens. Bioelectron. 2018, 100, 541-548. [CrossRef] [PubMed]

19. Melo, A.M.A.; Alexandre, D.L.; Furtado, R.F.; Borges, M.F.; Figueiredo, E.A.T.; Biswas, A.; Cheng, H.N.; Alves, C.R. Electrochemical immunosensors for Salmonella detection in food. Appl. Microbiol. Biotechnol. 2016, 100, 5301-5312. [CrossRef] [PubMed]

20. Zhu, D.; Yan, Y.R.; Lei, P.H.; Shen, B.; Cheng, W.; Ju, H.X.; Ding, S.J. A novel electrochemical sensing strategy for rapid and ultrasensitive detection of Salmonella by rolling circle amplification and DNA-AuNPs probe. Anal. Chim. Acta 2014, 846, 44-50. [CrossRef] [PubMed]

21. Freitas, M.; Viswanathan, S.; Nouws, H.P.A.; Oliveira, M.; Delerue-Matos, C. Iron oxide/gold core/shell nanomagnetic probes and CdS biolabels for amplified electrochemical immunosensing of Salmonella typhimurium. Biosens. Bioelectron. 2014, 51, 195-200. [CrossRef] [PubMed]

22. Brandao, D.; Liebana, S.; Campoy, S.; Cortes, P.; Alegret, S.; Pividori, M.I. Electrochemical magnetoimmunosensing of Salmonella based on nano and micro-sized magnetic particles. In Proceedings of the 8th Ibero-American Congress on Sensors (IBERSENSOR 2012), Carolina, Puerto Rico, 16-19 October 2012; pp. 1-7.

23. Hu, C.M.; Dou, W.C.; Zhao, G.J. Enzyme immunosensor based on gold nanoparticles electroposition and Streptavidin-biotin system for detection of S. pullorum \& S. gallinarum. Electrochim. Acta 2014, 117, 239-245.

24. Liebana, S.; Lermo, A.; Campoy, S.; Cortes, M.P.; Alegret, S.; Pividori, M.I. Rapid detection of Salmonella in milk by electrochemical magneto-immunosensing. Biosens. Bioelectron. 2009, 25, 510-513. [CrossRef] [PubMed]

25. Amini, K.; Ebralidze, I.I.; Chan, N.W.C.; Kraatz, H.-B. Characterization of TLR4/MD-2-modified Au sensor surfaces towards the detection of molecular signatures of bacteria. Anal. Methods 2016, 8, 7623-7631.

26. Grimont, P.A.D.; Weill, F. Antigenic Formulae of the Salmonella Serovars, 9th ed.; WHO Collaborating Centre for Reference and Research on Salmonella; Pasteur Institute: Paris, France, 2007.

27. Uludag, Y.; Esen, E.; Kokturk, G.; Ozer, H.; Muhammad, T.; Olcer, Z.; Basegmez, H.I.O.; Simsek, S.; Barut, S.; Gok, M.Y.; et al. Lab-on-a-chip based biosensor for the real-time detection of aflatoxin. Talanta 2016, 160, 381-388. [CrossRef] [PubMed]

28. Ciftci, G.Y.; Senkuytu, E.; Incir, S.E.; Yuksel, F.; Olcer, Z.; Yildirim, T.; Kilic, A.; Uludag, Y. First paraben substituted cyclotetraphosphazene compounds and DNA interaction analysis with a new automated biosensor. Biosens. Bioelectron. 2016, 80, 331-338. [CrossRef] [PubMed] 
29. Altintas, Z.; Uludag, Y.; Gurbuz, Y.; Tothill, I.E. Surface plasmon resonance based immunosensor for the detection of the cancer biomarker carcinoembryonic antigen. Talanta 2011, 86, 377-383. [CrossRef] [PubMed]

30. Altintas, Z.; Uludag, Y.; Gurbuz, Y.; Tothill, I. Development of surface chemistry for surface plasmon resonance based sensors for the detection of proteins and DNA molecules. Anal. Chim. Acta 2012, 712, 138-144. [CrossRef] [PubMed]

31. Altintas, Z.; Tothill, I.E. DNA-based biosensor platforms for the detection of TP53 mutation. Sens. Actuators B Chem. 2012, 169, 188-194. [CrossRef]

32. Pawula, M.; Altintas, Z.; Tothill, I.E. SPR detection of cardiac troponin T for acute myocardial infarction. Talanta 2016, 146, 823-830. [CrossRef] [PubMed]

33. Kim, H.J.; Park, S.H.; Lee, T.H.; Nahm, B.H.; Chung, Y.H.; Seo, K.H.; Kim, H.Y. Identification of Salmonella enterica serovar Typhimurium using specific PCR primers obtained by comparative genomics in Salmonella serovars. J. Food Prot. 2006, 69, 1653-1661. [CrossRef] [PubMed]

34. Altintas, Z. Surface plasmon resonance based sensor for the detection of glycopeptide antibiotics in milk using rationally designed nanoMIPs. Sci. Rep. 2018, 8, 11222. [CrossRef] [PubMed]

35. Garcia, T.; Revenga-Parraa, M.; Anorga, L.; Arana, S.; Pariente, F.; Lorenzo, E. Disposable DNA biosensor based on thin-film gold electrodes for selective Salmonella detection. Sens. Actuators B Chem. 2012, 161, 1030-1037. [CrossRef]

36. Zhang, D.C.; Yan, Y.R.; Li, Q.; Yu, T.X.; Cheng, W.; Wang, L.; Ju, H.X.; Ding, S.J. Label-free and high-sensitive detection of Salmonella using a surface plasmon resonance DNA-based biosensor. J. Biotechnol. 2012, 160, 123-128. [CrossRef] [PubMed]

(C) 2018 by the authors. Licensee MDPI, Basel, Switzerland. This article is an open access article distributed under the terms and conditions of the Creative Commons Attribution (CC BY) license (http:/ / creativecommons.org/licenses/by/4.0/). 